\title{
Degradation of Textile Dyes by Isolated Lysinibacillus Sphaericus Strain RSV-1 and Stenotrophomonas maltophilia Strain RSV-2 and Toxicity Assessment of Degraded Product
}

\section{Rajeswari $\mathbf{K}^{\mathbf{1 *}}$, Subashkumar $\mathbf{R}^{\mathbf{2}}$ and Vijayaraman $\mathbf{K}^{\mathbf{3}}$}

${ }^{1}$ Research and Development Centre, Bharathiar University, Coimbatore, Tamil Nadu, India

${ }^{2} P G$ \& Research Department of Biotechnology, Kongunadu Arts and Science College, Coimbatore, Tamil Nadu, India

${ }^{3}$ KSG College of Arts and science, Coimbatore, Tamil Nadu, India

\begin{abstract}
An attempt was made to study the toxic nature of dye degraded product(s) which was degraded by previously isolated two potential strains namely Lysinibacillus sphaericus RSV-1 and stenotrophomonas maltophilia RSV-2. The phytotoxicity and cytotoxicity of degraded product(s) were tested on Triticum aestivum (co w) and human embryonic kidney cell line (HEK 293) respectively. Results revealed that the degraded product(s) was nontoxic in nature with respect to phytotoxicity as well as cytotoxicity study. Further the strains were utilized for the treatment of real textile dyewaste effluent and the result found that there was considerable reduction in Biological Oxygen Demand (BOD), Chemical Oxygen Demand (COD) and Total Organic Carbon (TOC) of real textile effluent. Therefore the strains could be effectively utilized for the treatment of real textile dye effluent having high concentration of reactive dyes.
\end{abstract}

Keywords: Textile dye waste effluent; Lysinibacillus sp; Stenotrophomonas sp; Physico-chemical parameter; Waste water treatment

\section{Introduction}

With the increased demand for textile products, the textile industry and its wastewater have been increasing proportionally, making it one of the main sources of severe pollution problems worldwide. In particular, the release of coloured effluents into the environment is undesirable, not only because of their colour, but also because many dyes from wastewater and their breakdown products are toxic and/or mutagenic to life [1]. In India, an average mill discharges about 1.5 million litres of contaminated effluent per day, which leads to chronic and acute toxicity [2]. Considering the volume generated and the effluent composition, textile industry wastewater is rated as the most polluting among all industrial sectors [3]. The effluents from textile and dyeing industries have high Chemical oxygen demand (COD), Biochemical oxygen demand (BOD), colour, $\mathrm{pH}$, and also it contains metal ions, hence it is very difficult to treat such effluents [4]. Textile industries generate millions of liters of untreated effluents per day which are directly discharged into drinking water resources, such as rivers and lakes. This alters $\mathrm{pH}$, increases $\mathrm{BOD}$ and $\mathrm{COD}$ and gives intense coloration [5]. Dye wastewaters are usually treated using physicochemical methods such as flocculation, coagulation, adsorption, membrane filtration, precipitation, irradiation, ozonization and Fenton's oxidation [6]. These methods are effective but may generate significant amounts of chemical sludge, whose disposal in secure landfill increases process cost [7]. There are several studies describing decolorization of reactive dyes mediated by pure bacterial culture such as, Pseudomonas sp. SUK1 for Reactive Red 2 [8]; Exiguobacterium sp. RD3 for Navy Blue HE2R (Reactive Blue 172) [9]; Rhizobium radiobacter MTCC 8161 for Reactive Red 141 [10]; Pseudomonas aeruginosa NBAR12 for Reactive Blue 172 [11] and isolated bacterium KMK48 for the degradation of various sulfonated reactive azo dyes [12]. It is very important to know whether biodegradation of a dye leads to detoxification of the dye or not. This can be done by performing toxicity test of the original dye and its biodegradation products. Many studies have shown that reactive dyes can cause allergic dermatoses and respiratory diseases $[13,14]$. In order to assess the effect of xenobiotic compounds on cell, it is important to determine the cytotoxicity concentration of the dye or its degraded compound. Our previously isolated potential bacterial strains [15] from textile dyewaste effluent were utilized in the present study. An attempt was made to determine the toxic nature of the dye metabolites based on phytotoxicity and cytotoxicity test, further the strains were used to treat real textile effluents and physico chemical parameters of treated and untreated effluents were analysed. Two potential strains namely Lysinibacillus sphaericus RSV1 and stenotrophomonas maltophilia RSV-2 were isolated from textile dyewaste effluent capable of decolorizing four different mixed reactive dyes namely Blue RR, Black B, Red RR and Yellow RR up to 2700mg1 and $2100 \mathrm{mg}-1$ respectively with 50-60 percent decolorization within 48-70 h of incubation [16]. Strain Lysinibacillus sp ZB-1, the first one of this genus, was found to possess the ability to metabolize fomesafen. Lysinibacillus are able to survive under extremely harsh conditions, which make them ideal candidates for bioremediation of contaminated environments [17]. Originally, this genus was Bacillus sp. and was transferred into this genus as Lysinibacillus sp. in 2007 [18]. A bacterial strain AAP56, isolated from a polluted soil (from Kelibia city) and identified as Stentrophomonas maltophilia, was particularly interesting for its ability to decolorize recalcitrant dyes of an industrial effluent SITEX Black [19]. This strain can also decolorize some synthetic dyes such as Methylene Blue, Toluidine Blue, Methyl Green, IndigoBlue, Neutral Red, Congo red, Methyl Orange and Reactive Pink [20]. Many studies have shown that reactive dyes can cause allergic dermatoses and respiratory diseases [21-24]. The result of a clinical and immunological

*Corresponding author: Rajeswari K, Research and Development Centre Bharathiar University, Coimbatore, Tamil Nadu, India, Tel: 09944933846; E-mail rajimicro_grd@yahoo.co.in

Received April 04, 2014; Accepted May 19, 2014; Published May 23, 2014

Citation: Rajeswari K, Subashkumar R, Vijayaraman K (2014) Degradation of Textile Dyes by Isolated Lysinibacillus Sphaericus Strain RSV-1 and Stenotrophomonas maltophilia Strain RSV-2 and Toxicity Assessment of Degraded Product. J Environ Anal Toxicol 4: 222. doi: 10.4172/2161-0525.1000222

Copyright: () 2014 Rajeswari K, et al. This is an open-access article distributed under the terms of the Creative Commons Attribution License, which permits unrestricted use, distribution, and reproduction in any medium, provided the original author and source are credited. 
Citation: Rajeswari K, Subashkumar R, Vijayaraman K (2014) Degradation of Textile Dyes by Isolated Lysinibacillus Sphaericus Strain RSV-1 and Stenotrophomonas maltophilia Strain RSV-2 and Toxicity Assessment of Degraded Product. J Environ Anal Toxicol 4: 222. doi: 10.4172/21610525.1000222

investigation of respiratory disease indicated that about $15 \%$ of 400 workers handling reactive dyes experienced work-related respiratory and nasal symptoms [25]. Recent toxicological studies with the azo dye Red HE3B (Reactive Red 120), before and after bacterial treatments, showed that the dye was able to induce oxidative stress and a high frequency of chromosome aberrations and micronuclei in root cells of A. cepa, when compared to the effects caused by its metabolites [26]. The textile industries are to satisfy the ever growing demands in terms of quality, variety, fastness and other technical requirements, but the use of dye stuffs has become increasingly a subject of environmental concern. Therefore, it is essential to evolve regulations designated to improve the health and safety and the human and natural environment [27].

\section{Materials and Methods}

\section{Microorganisms and growth media}

Previously isolated bacterial strains Lysinibacillus sphaericus strain RSV-1 and stenotrophomonas maltophilia strain RSV-2 were cultured and maintained on Nutrient agar medium with the composition ( $\mathrm{g}$ $\mathrm{L}^{-1}$ ) of Peptone (5.0); Yeast extract (2.0); Beef extract (3.0); $\mathrm{NaCl}(5.0)$; agar (16.0) $\mathrm{pH} 7.0 \pm 0.02$. All the decolorization experiments were performed in Mineral Salts Medium (MSM) of $\mathrm{pH} 7.0$ contained $\left(\mathrm{g} \mathrm{L}^{-1}\right)$ the following composition $\mathrm{NaCl}(1.0), \mathrm{CaCl}_{2} \cdot 2 \mathrm{H}_{2} \mathrm{O}(0.1), \mathrm{MgSO}_{4} \cdot 7 \mathrm{H}_{2} \mathrm{O}$ (0.5), $\mathrm{KH}_{2} \mathrm{PO}_{4}(1.0)$ and $\mathrm{Na}_{2} \mathrm{HPO}_{4}$ (1.0). Decolorization experiment was performed in mixture of ten reactive dyes namely Yellow ME4GL, Blue RR, Red RR, Yellow RR, Red M5B, Blue MR, Deep Black RR, Yellow MERL, Red ME4BL and Golden Yellow MR. These strains could able to decolourise more than four mixed dye hence further experiments were performed with ten mixed dyes. Dyes were procured from textile dyeing unit in Tirupur. About 1000 ppm of stock was maintained by adding equal amount of each dye.

\section{Decolorization study}

The superior Strain RSV-1 was used in toxicity studies was inoculated separately in nutrient broth medium and incubated at $30^{\circ} \mathrm{C}$ for 24 hrs. After incubation cells were centrifuged at $6000 \mathrm{rpm}$ for 15 minutes. Pellets were dissolved in MSM containing $0.5 \%$ yeast extract. Cell density of $1.0 \mathrm{OD}$ at $600 \mathrm{~nm}$ was made for decolorization experiment. The medium to inoculum ratio was maintained at 50:1. MSM was prepared by adding ten different reactive dyes with initial concentration of $500 \mathrm{ppm}$, after complete decolorization, another 500 ppm was added. Complete decolorizarion was achieved within 24$30 \mathrm{hrs}$ of incubation rather 5-6 hrs (data provided in supplementary material) when four mixed dyes were used and then, the cell-free supernatant was collected after decolorization was extracted first with ethyl acetate to extract the biotransformed products and the aqueous phase was further extracted with n-butanol to extract the residual dye. Degraded product(s) was analysed using TLC, the developing solvent systems used were ethyl acetate:hexane $(2: 3, \mathrm{v} / \mathrm{v})$ for biotransformed intermediates/products and ethyl acetate:methanol (7:3, v/v) for residual dye. The bands of aromatic components were observed under UV light $(365 \mathrm{~nm})$ and other bands were observed by exposing the plates to iodine vapor in an iodine chamber. Ethyl acetate is rarely selected as a reaction solvent because it is prone to hydrolysis and transesterification. The aqueous phase, thus obtained, was subsequently extracted twice with $n$-butanol to extract the residual dye (extract-2), as dye was more soluble in n-butanol [28].

\section{Phytotoxicity study}

The degraded metabolites of mixed dye, extracted in ethyl acetate were dried and dissolved in water to form the final concentration of $1,000 \mathrm{ppm}$ were used for phytotoxicity studies. The phytotoxicity study was carried out at room temp $\left(30 \pm 2{ }^{\circ} \mathrm{C}\right)$ in relation to Triticum aestivum ( $\mathrm{co} \mathrm{w}$ ) seeds (ten seeds) by watering separately. The seeds were procured from the Department of Millets, TNAU, Coimbatore. About $5 \mathrm{ml}$ samples of mixed dye and its degradation product $(1,000$ ppm) was supplied per day. Control set was carried out using plain water at the same time. Length of plumule (shoot), radical (root) and germination (\%) was recorded after 7 days.

\section{Cytotoxicity study (In vitro cell proliferation assay)}

Cell line: The human embryonic kidney cell line (HEK 293) was obtained from National Centre for Cell Science (NCCS), Pune, and grown in Eagles Minimum Essential Medium (EMEM) containing $10 \%$ fetal bovine serum (FBS). All cells were maintained at $37^{\circ} \mathrm{C}, 5 \%$ $\mathrm{CO}_{2}, 95 \%$ air and $100 \%$ relative humidity. Maintenance cultures were passaged weekly, and the culture medium was changed twice a week.

Cell treatment: The monolayer cells were detached with trypsinethylene diamine tetra acetic acid (EDTA) to make single cell suspensions and viable cells were counted using a hemocytometer and diluted with medium with $5 \%$ FBS to give final density of $1 \times 10^{5}$ cells $/ \mathrm{ml}$. one hundred microlitres per well of cell suspension were seeded into 96-well plates at plating density of 10,000 cells/well and incubated to allow for cell attachment at $37^{\circ} \mathrm{C}, 5 \% \mathrm{CO}_{2}, 95 \%$ air and $100 \%$ relative humidity. After $24 \mathrm{hrs}$, the cells were treated with at least six concentrations of degraded samples. They were initially dissolved in dimethylsulfoxide (DMSO) and stored frozen prior to use. The obtained product was dissolved in DMSO to prepare a final concentration $1 \mathrm{mg} /$ $\mathrm{ml}$. The samples were further diluted in serum free medium and $100 \mu \mathrm{l}$ per well was added to plates to obtain final concentrations of 500,250, $125,62.5$, and $31.25 \mu \mathrm{g} / \mathrm{ml}$. The final volume in each well was $200 \mu \mathrm{l}$ and the plates were incubated at $37^{\circ} \mathrm{C}, 5 \% \mathrm{CO}_{2}, 95 \%$ air and $100 \%$ relative humidity for $48 \mathrm{hrs}$. The medium containing without samples were served as control. Triplicate was maintained for all concentrations.

MTT assay: MTT is a yellow water soluble tetrazolium salt. A mitochondrial enzyme in living cells, succinate-dehydrogenase, cleaves the tetrazolium ring, converting the MTT to an insoluble purple formazan. Therefore, the amount of formazan produced is directly proportional to the number of viable cells. After $48 \mathrm{hrs}$ of incubation, $15 \mu \mathrm{l}$ of MTT $(5 \mathrm{mg} / \mathrm{ml})$ in phosphate buffered saline (PBS) was added to each well and incubated at $37^{\circ} \mathrm{C}$ for $4 \mathrm{hrs}$. The medium with MTT was then flicked off and the formed formazan crystals were solubilized in $100 \mu \mathrm{l}$ of DMSO and then measured the absorbance at $570 \mathrm{~nm}$ using micro plate reader. The percentage cell viability was then calculated with respect to control as follows:

\section{$\%$ Cell viability $=[\mathrm{A}]$ Test $/[\mathrm{A}]$ controlx100}

\section{Treatment of real dye waste effluent by RSV1 and RSV2}

The decolorization and biodegradation capacity of RSV-1 and RSV-2 was performed on real textile effluent. For the experiment, raw effluent was collected from one of the CETP unit located in Tirupur and the strains were inoculated individually as well as in consortium form. The set up was maintained as per optimized physicochemical condition. Two controls were maintained, control A (effluent without any nutrition supplement); control B (effluent with $0.5 \%$ of soya powder); RSV-1(effluent inoculated with RSV-1 strain along with $0.5 \%$ of soya powder); RSV-2 (effluent inoculated with RSV-2 strain with $0.5 \%$ of soya powder); CRM (effluent contains strain RSV-1 and RSV-2 
Citation: Rajeswari K, Subashkumar R, Vijayaraman K (2014) Degradation of Textile Dyes by Isolated Lysinibacillus Sphaericus Strain RSV-1 and Stenotrophomonas maltophilia Strain RSV-2 and Toxicity Assessment of Degraded Product. J Environ Anal Toxicol 4: 222. doi: 10.4172/21610525.1000222

Page 3 of 5

along with $0.5 \%$ of soya powder). All the physico-chemical parameters were analysed as per the method of APHA [29].

\section{Results and Discussion}

In our previous study about 112 bacterial strains were isolated from dyewaste effluent. Based on various screening methods, the two most competent strains were selected for further studies [15]. In acclimatization study, these two bacterial strains RSV-1 and RSV-2 decolorized four different mixed reactive dyes namely Blue RR, Black B, Red RR and Yellow RR up to $2700 \mathrm{mg}^{-\mathrm{L}}$ and $2100 \mathrm{mg}^{-\mathrm{L}}$ respectively with 50-60 percent decolorization within 48-70 hrs of incubation (Tables S1 and S2). The strains were identified as Lysinibacillus sphaericus RSV1 and Stenotrophomonas maltophilia RSV-2 1 based on morphology, physiochemical properties, and the results of $16 \mathrm{~S}$ ribosomal RNA (rRNA) gene sequence analysis [16]. The sequences of RSV-1 and RSV-2 were deposited in Gen Bank database under accession number JF502569 and JF502570 respectively. The identification of microorganisms capable of assimilation or removal of textile dyes is one approach to reduce environmental pollution by textile dyes. Bioremediation of the textile effluents is an attractive method of color removal due to its environmental friendly technology. Hence, it is of outstanding interest to find an effective microflora and biochemical approach for the decolorization and detoxification of textile wastewater [30].

\section{Phytotoxicity analysis of degraded product}

Most common methods employed to study phytotoxicity are monitoring of seed germination and plant growth. As dyewaste from industries are most commonly discharged to the nearby agricultural area and water bodies, it was important to reveal the toxicity of Reactive dyes and its degraded metabolites on plant systems. Germination (\%) of Triticum aestivum seeds was found to be less with mixed reactive dyes as compared with its degraded metabolites. The phytotoxicity study showed that length of plumule and radical was affected in case of the dyes whereas with degraded metabolites it showed significant growth, compared to control (Table 1), which indicate that, the isolated RSV1 was not only able to decolorize mixed dyes but was also able to detoxify it. The mean of plumule length and radical length of T. aestivum was $13.30 \pm 1.161 \mathrm{~cm}$ and $9.25 \pm 0.75 \mathrm{~cm}$, respectively of 10 seeds in distilled water as a control with $100 \%$ germination. When seeds were treated with $500 \mathrm{ppm}$ concentration of mixed reactive dyes, the plumule length and radical length was found to be $3.57 \pm 1.59$ and 2.05 $\pm 0.83 \mathrm{~cm}$, respectively with $30 \%$ germination. Whereas when treated with the degraded metabolites the plumule length and radical length was found to be $12.34 \pm 0.73$ and $8.71 \pm 0.50 \mathrm{~cm}$, respectively with $80 \%$ germination when treated with $1000 \mathrm{ppm}$ degradation product . This indicates the less toxic nature of the degradation product to the plants. We found that the degraded metabolites were non-toxic to the test plant; hence the strains could be utilized for the treatment of real textile effluent. The relative sensitivity towards the dye DR5B and its degradation products in relation to T.aestivum was studied by Jadhav et al., [31]. Parshetti et al. also showed germination of T. aestivum was less with malachite green treatment as compared to its degradation

\begin{tabular}{|l|c|c|c|}
\hline & Germination (\%) & Plumule (cm) & Radial (cm) \\
\hline Distilled water & 100 & $13.30 \pm 1.161$ & $9.25 \pm 0.75$ \\
\hline Mixed dye & 30 & $3.57 \pm 1.59$ & $2.05 \pm 0.83$ \\
\hline Metabolites & 80 & $12.34 \pm 0.73$ & $8.71 \pm 0.50$ \\
\hline
\end{tabular}

Values of mean of ten germinated seeds of three sets SEM $( \pm)$

Table 1: Phytotoxicity study of reactive mixed dye and metabolites on Triticum aestivum $\mathrm{CO}(\mathrm{W})$

\begin{tabular}{|l|c|c|c|c|c|c|}
\hline Concentration & $\begin{array}{c}\mathbf{3 1 . 2 5} \\
\mathbf{\mu g} / \mathbf{m l}\end{array}$ & $\begin{array}{c}\mathbf{6 2 . 5} \\
\boldsymbol{\mu} \mathbf{g} / \mathbf{m l}\end{array}$ & $\mathbf{1 2 5} \mathbf{\mu g} / \mathbf{m l}$ & $\mathbf{2 5 0} \mathbf{\mu g} / \mathbf{m l}$ & $\begin{array}{c}\mathbf{5 0 0} \mathbf{\mu g} / \\
\mathbf{~ m l}\end{array}$ & Control1 \\
\hline \multirow{3}{*}{$\begin{array}{l}\text { Absorbance at } \\
570 \mathrm{~nm}\end{array}$} & 0.274 & 0.255 & 0.263 & 0.248 & 0.223 & 0.284 \\
\cline { 2 - 7 } & 0.264 & 0.264 & 0.248 & 0.255 & 0.218 & 0.271 \\
\cline { 2 - 7 } & 0.275 & 0.27 & 0.255 & 0.249 & 0.215 & 0.271 \\
\cline { 2 - 7 } & 0.271 & 0.263 & 0.255333 & 0.250667 & 0.218667 & 0.275333 \\
\hline Average & 0.271 & 0.263 & 0.255333 & 0.250667 & 0.218667 & 0.275333 \\
\hline
\end{tabular}

1- Contains no added substances but only the cells

Table 2: Different concentrations of metabolites and their absorbance.

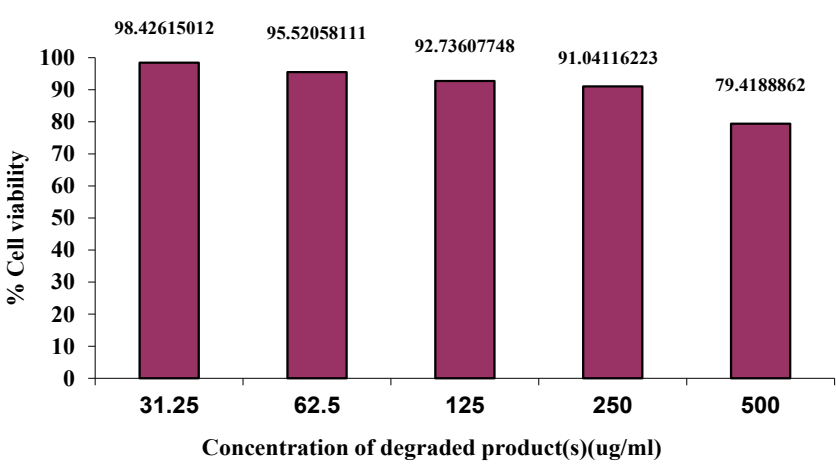

Figure 1: Different concentration of metabolites vs \% cell (HEK 293) viability.

product and distilled water [32].

\section{Cytotoxicity analysis of degraded product}

The cytotoxicity study was conducted to check the toxic nature of degraded metabolites on human embryonic kidney cell line (HEK 293) using MTT assay. The assay was performed with varying concentration of degraded product ranged from 31.25-500 $\mu \mathrm{g} / \mathrm{ml}$ (Table 2) and percentage cell viability was observed in the range of 79.41-98.42 (Figure 1) since the degraded product at high concentration because only a mild interference in cell viability, hence it's said to be non-toxic in nature. We performed MTT for mixed dye, but we could not interpret the result since it interefere with the colour, also the cells were not clearly detected when observed under inverted microscope (S3). Cytotoxicity of DR28 dyes at various stages of biodegradation by the strain Bacillus velezensis $\mathrm{AB}$ was studied by Bafana et al. [33]. Cytotoxicity was tested on HL-60 cell line using MTT assay. Toxicity towards HL-60 cells increased on the $3 \mathrm{rd}$ day, followed by gradual reduction up to 15 th day $(p<0.01)$. The mouse fibroblast cell line from subcutaneous connective tissue (L929 cell line) was utilized or testing the parent dye Reactive Red 141 and Reactive Red 2 dye and their metabolites produced by the strain Bacillus lentus [34]. Eczema, contact dermatitis, asthma, chronic bronchitis, tuberculosis, haematoma, bladder cancer and irritation to eyes, have been reported amongst the workers of textile industries in Sanganer [35].

\section{Treatment of real dye effluent by the strains RSV1 and RSV2}

The decolorization and degradation ability of RSV-1, RSV-2 and consortium (CRM) was determined on real textile effluent. The study effluent was collected from CETP plant and the strains were inoculated individually as well as in consortium form (Table 3 ). There was an average reduction in BOD (76\%), COD (62.48\%) and TOC (47.57\%) in the effluent containing RSV-1 strain was found. The percent reduction of BOD, COD and TOC for RSV-2 and consortium was found to be $36.86 \%, 60.71 \%, 44.48 \%$ and $56.56 \%, 67.10 \%$ and $48.96 \%$ respectively, 
Citation: Rajeswari K, Subashkumar R, Vijayaraman K (2014) Degradation of Textile Dyes by Isolated Lysinibacillus Sphaericus Strain RSV-1 and Stenotrophomonas maltophilia Strain RSV-2 and Toxicity Assessment of Degraded Product. J Environ Anal Toxicol 4: 222. doi: 10.4172/21610525.1000222

Page 4 of 5

\begin{tabular}{|c|c|c|c|c|c|c|c|}
\hline Parameters & Control A & Control B & RSV-1 & RSV-2 & CRM & Treatment Time(hrs) & РСВ Standard \\
\hline Color & Reddish Black & Light black & Colourless & Light black & Colourless & 12 & - \\
\hline Color(pt/co) & 1245 & 397 & 103 & 412 & 87 & 12 & - \\
\hline $\mathrm{EC}(\mathrm{mohs} \mathrm{cm})-1$ & 12410 & 13786 & 13367 & 13229 & 13787 & 24 & - \\
\hline $\mathrm{pH}$ & 8.3 & 7.5 & 8.0 & 8.2 & 7.8 & 24 & $5.5-9.0$ \\
\hline \% Decolorization & 16.09 & 56.89 & 87.05 & 53.88 & 89.56 & 30 & - \\
\hline Total Suspended Solids (mg/l) & 165 & 188 & 176 & 185 & 194 & 30 & $50-150 \mathrm{mg} / \mathrm{l}$ \\
\hline Total Dissolved Solids(mg/l) & 8054 & 8215 & 8764 & 8973 & 8765 & 30 & $\begin{array}{c}\text { Not more than } 3,000 \\
\mathrm{mg} / \mathrm{l}\end{array}$ \\
\hline Total hardness as $\mathrm{CaCo} 3(\mathrm{mg} / \mathrm{l})$ & 345 & 367 & 398 & 365 & 415 & 30 & - \\
\hline $\mathrm{BOD}(\mathrm{mg} / \mathrm{l})$ & 198 & 69 & 47 & 125 & 86 & 48 & $20-60 \mathrm{mg} / \mathrm{l}$ \\
\hline $\mathrm{COD}(\mathrm{mg} / \mathrm{l})$ & 845 & 320 & 317 & 332 & 278 & 48 & $120-400 \mathrm{mg} / \mathrm{l}$ \\
\hline Total Alkalinity(mg/l) & 1435 & 1539 & 1545 & 1533 & 1503 & 48 & - \\
\hline Chlorides(mg/l) & 759 & 722 & 673 & 747 & 681 & 48 & - \\
\hline Sulphats (mg/l) & 1466 & 1410 & 1449 & 1424 & 1398 & 48 & - \\
\hline TOC(mg/l) & 1650 & 987 & 865 & 916 & 842 & 48 & - \\
\hline
\end{tabular}

Control $A=$ effluent without any nutritional supplement; control B =effluent with $0.5 \%$ of soya powder; RSV-1(effluent inoculated with RSV-1 strain along with $0.5 \%$ of soya powder); RSV-2 (effluent inoculated with RSV-2 strain with $0.5 \%$ of soya powder); CRM (effluent contains strain RSV-1 and RSV-2 along with $0.5 \%$ of soya powder)

Table 3: Physico chemical parameters of treated and untreated real textile effluent using effective strains.

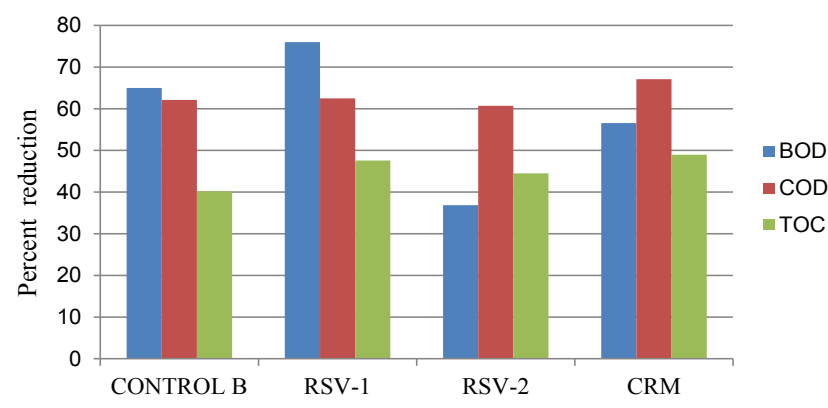

Figure 2: Comparative study of percent reduction of BOD, COD and TOC.

whereas in control B, the percent reduction of BOD, COD and TOC was found to be $65 \%, 62.13 \%$ and $40.18 \%$ respectively within 48 hrs (Figure 2). Considerable differences were not observed in other parameters. Based on the experiment, we could conclude that comparatively our strain RSV-1 was a good candidate for effective decolorization of real textile effluent. The ability of the strain to tolerate, decolorize and degrade azo dyes at high concentration gives it an advantage for treatment of textile industry wastewaters. However, potential of culture needs to be demonstrated for its application in treatment of real dye bearing wastewaters using appropriate bioreactors. Consortium-AP of Aspergillus ochraceus NCIM-1146 fungi and Pseudomonas sp. SUK1 bacterium achieved a significant reduction in COD (96\%), BOD (82\%) and TOC (48\%) of textile effluent [36].

\section{Conclusion}

This is the first report to date, and to our knowledge, that investigates the use of Lysinibacillus sphaericus RSV-1 and Stenotrophomonas maltophilia RSV-2 culture in treating industrial wastewaters containing various types of dyes. While treating the real textile effluent, the reduction of BOD, COD and TOC shows that the strains could mineralize the dyes. Thus our microbes can be a suitable candidate for the treatment of real effluent containing high concentration of textile dyes.

\section{Acknowledgment}

Authors acknowledge the Tamil Nadu State Council for Science and Technology (TNSCST) for financial support for carrying out this work.

\section{References}

1. Weisburger $\mathrm{JH}$ (2002) Comments on the history and importance of aromatic and heterocyclic amines in public health. Mutat Res 506-507: 9-20.

2. Sheth NT, Dave SR (2009) Optimisation for enhanced decolourization and degradation of Reactive Red BS C.I. 111 by Pseudomonas aeruginosa NGKCTS. Biodegradation 20: 827-836.

3. Mezohegyi G, Fabregat A, Font J, Bengoa C, Stuber F (2009) Advanced Bioreduction of Commercially Important Azo Dyes: Modeling and Correlation with Electrochemical Characteristics. Ind Eng Chem Res 48: 7054-7059.

4. Senan RC, Abraham TE (2004) Bioremediation of textile azo dyes by aerobic bacterial consortium. Biodegradation 15: 275-280.

5. Telke AA, Joshi SM, Jadhav SU, Tamboli DP, Govindwar SP (2010) Decolorization and detoxification of Congo red and textile industry effluent by an isolated bacterium Pseudomonas sp. SU-EBT. Biodegradation 21: 283-296.

6. Lodha B, Chaudhari S (2007) Optimization of Fenton-biological treatment scheme for the treatment of aqueous dye solutions. J Hazard Mater 148: 459-466.

7. Kumar K, Saravana Devi S, Krishnamurthi K, Gampawar S, Mishra N, et al. (2006) Decolorisation, biodegradation and detoxification of benzidine based azo dye. Bioresour Technol 97: 407-413.

8. Kalyani DC, Telke AA, Dhanve RS, Jadhav JP (2009) Ecofriendly biodegradation and detoxification of Reactive Red 2 textile dye by newly isolated Pseudomonas sp. SUK1. J Hazard Mater 163: 735-742.

9. Dhanve RS, Shedbalkar UU, Jadhav JP (2008) Biodegradation of diazo reactive dye navy blue HE2R (Reactive blue 172) by an isolated Exiguobacterium sp. RD3. Biotechnol Bioprocess Eng 13: 53-60.

10. Telke A, Kalyani D, Jadhav J, Govindwar S (2008) Kinetics and Mechanism of Reactive Red 141 Degradation by a Bacterial Isolate Rhizobium radiobacter MTCC 8161. Acta Chim Slov 55: 320-329.

11. Bhatt N, Patel KC, Keharia H, Madamwar D (2005) Decolorization of diazo-dye Reactive Blue 172 by Pseudomonas aeruginosa NBAR12. J Basic Microbiol 45: 407-418

12. Kodam KM, Soojhawon I, Lokhande PD, Gawai KR (2005) Microbial decolorization of reactive azo dyes under aerobic conditions. World J Microbio Biotechnol 21: 367-370.

13. Estlander $T$ (1988) Allergic dermatoses and respiratory diseases from reactive dyes. Contact Dermatitis 18: 290-297.

14. Hatch KL, Maibach HI (1995) Textile dye dermatitis. J Am Acad Dermatol 32 631-639.

15. Rajeswari K, Subashkumar R, Vijayaraman K (2011) Biodegradation of Mixed Textile Dyes by Bacterial Strains Isolated from Dyewaste Effluent. Res J Environl Toxicol 5: 97-107.

16. Rajeswari K, Subashkumar R, Vijayaraman K (2013) Decolorization and 
Citation: Rajeswari K, Subashkumar R, Vijayaraman K (2014) Degradation of Textile Dyes by Isolated Lysinibacillus Sphaericus Strain RSV-1 and Stenotrophomonas maltophilia Strain RSV-2 and Toxicity Assessment of Degraded Product. J Environ Anal Toxicol 4: 222. doi: 10.4172/21610525.1000222

Degradation of Textile Dyes by Stenotrophomonas maltophilia RSV-2. Int $J$ Environ Bioremediation Biodegradation 1: 60-65.

17. Liang B, Lu P, Li H, Li R, Li S, et al. (2009) Biodegradation of fomesafen by strain Lysinibacillus sp. ZB-1 isolated from soil. Chemosphere 77: 1614-1619.

18. Ahmed I, Yokota A, Yamazoe A, Fujiwara T (2007) Proposal of Lysinibacillus boronitolerans gen. nov. sp. nov., and transfer of Bacillus fusiformis to Lysinibacillus fusiformis comb. nov. and Bacillus sphaericus to Lysinibacillus sphaericus comb. nov. Int J Syst Evol Microbiol 57: 1117-1125.

19. Galai S, Limam F, Marzouki MN (2010) Decolorization of an industrial effluent by free and immobilized cells of Stenotrophomonas maltophilia AAP56. Implementation of efficient down flow column reactor. World $\mathrm{J}$ Microbiol Biotechnol 26: 1341-1347.

20. Galai S, Limam F, Marzouki MN (2009) A new Stenotrophomonas maltophilia strain producing laccase. Use in decolorization of synthetics dyes. Appl Biochem Biotechnol 158: 416-431.

21. Estlander $T$ (1988) Allergic dermatoses and respiratory diseases from reactive dyes. Contact Dermatitis 18: 290-297.

22. Hatch KL, Maibach HI (1995) Textile dye dermatitis. J Am Acad Dermatol 32 631-639.

23. Manzini BM, Motolese A, Conti A, Ferdani G, Seidenari S (1996) Sensitization to reactive textile dyes in patients with contact dermatitis. Contact Dermatitis 34: $172-175$.

24. Nilsson R, Nordlinder R, Wass U, Meding B, Belin L (1993) Asthma, rhinitis, and dermatitis in workers exposed to reactive dyes. $\mathrm{Br} \mathrm{J}$ Ind Med 50: 65-70.

25. Docker A, Wattie JM, Topping MD, Luczynska CM, Newman Taylor AJ, et al. (1987) Clinical and immunological investigations of respiratory disease in workers using reactive dyes. $\mathrm{Br} \mathrm{J}$ Ind Med 44: 534-541.

26. Phugare SS, Kalyani DC, Patil AV, Jadhav JP (2010) Textile dye degradation by bacterial consortium and subsequent toxicological analysis of dye and dye metabolites using cytotoxicity, genotoxicity and oxidative stress studies. J Hazard Mater 186: 713-723.
27. Mathur N, Bhatnagar P, Sharma P (2012) Review of the Mutagenicity of Textile Dye Products. Uni J Environ Res Technol 2: 1-18.

28. Sharma DK, Saini HS, Singh M, Chimni SS, Chadha BS (2004) Biological treatment of textile dye acid violet-17 by bacterial consortium in an up-flow immobilized cell bioreactor. Lett Appl Microbiol 38: 345-350.

29. ljzerman MM, Falkinham JO, Reneau RB, Hagedorn C (1994) Field evaluation of two colorimetric coliphage detection methods. Appl Environ Microbiol 60 826-830.

30. Gomare SS, Kalme SD, Govindwar SP (2009) Biodegradation of Navy Blue-3G by Brevibacillus laterosporus MTCC 2298. Acta Chim Slov 56: 789-796.

31. Jadhav UU, Dawkar VV, Ghodake GS, Govindwar SP (2008) Biodegradation of Direct Red 5B, a textile dye by newly isolated Comamonas sp. UVS. J Hazard Mater 158: 507-516.

32. Parshetti G, Kalme S, Saratale G, Govindwar S (2006) Biodegradation of Malachite green by Kocuria rosea MTCC 1532. Acta Chimica Slovenica 53 : 492-498.

33. Bafana A, Chakrabarti T, Devi SS (2008) Azoreductase and dye detoxification activities of Bacillus velezensis strain AB. Appl Microbiol Biotechnol 77: 1139 1144.

34. Oturkar CC, Patole MS, R Gawai K, Madamwar D (2013) Enzyme based cleavage strategy of Bacillus lentus BI377 in response to metabolism of azoic recalcitrant. Bioresour Technol 130: 360-365.

35. Usha M (1989) Impact analysis of Industries in Sanganer. P.G. Diploma Field Study Report submitted to Indira Gandhi center for HEEPS, University of Rajasthan, Jaipur (India)

36. Lade HS, Waghmode TR, Kadam AA, Govindwar SP (2012) Enhanced biodegradation and detoxification of disperse azo dye Rubine GFL and textile industry effluent by defined fungal-bacterial consortium. Int Biodeter Biodegrad 72: 94-107. 